Article

\title{
Cladoceran (Crustacea) Niches, Sex, and Sun Bathing-A Long-Term Record of Tundra Lake (Lapland) Functioning and Paleo-Optics
}

\author{
Liisa Nevalainen $^{1, * \mathbb{C}}$, E. Henriikka Kivilä ${ }^{1}$, Marttiina V. Rantala ${ }^{1,2}$ and Tomi P. Luoto ${ }^{1}$ \\ 1 Faculty of Biological and Environmental Sciences, Ecosystems and Environment Research Programme, \\ University of Helsinki, Niemenkatu 73, 15140 Lahti, Finland; henriikka.kivila@helsinki.fi (E.H.K.); \\ marttiina.rantala@helsinki.fi (M.V.R.); tomi.luoto@helsinki.fi (T.P.L.) \\ 2 CNR-Water Research Institute (IRSA), Unit Verbania, VialeTonolli 50, 28922 Verbania, Italy \\ * Correspondence: liisa.nevalainen@helsinki.fi
}

Received: 2 September 2019; Accepted: 24 September 2019; Published: 27 September 2019

\begin{abstract}
Under fundamental ecosystem changes in high latitude lakes, a functional paleolimnological approach may increase holistic understanding of lake responses and resilience to climate warming. A 2000-year sediment record from Lake Loažžejávri in the tundra of northern Finnish Lapland was examined for fossil Cladocera assemblages to examine long-term environmental controls on aquatic communities. In addition, cladoceran functional attributes, including functional diversity (FD), UV absorbance (ABS $\mathrm{AV}_{\mathrm{UV}}$ ) of Alona carapaces, and sexual reproduction (ephippia) in Bosmina and Chydoridae were analyzed. Cladoceran communities responded to a major change in benthic habitat quality, reflected as elevated (increasingly benthic) sediment organic matter $\delta^{13} \mathrm{C}$ signal since the 17th century. FD fluctuations showed association with climate oscillation, FD being generally higher during warm climate periods. These ecological changes were likely attributable to diversification of littoral-benthic consumer habitat space. $\mathrm{ABS}_{\mathrm{UV}}$, irrespective of increases during the Little Ice Age (LIA) due to higher UV transparency of lake water, was lower under increasing autochthony (benthic production) suggesting establishment of physical UV refugia by the benthic vegetative substrata. Bosmina ephippia exhibited a decreasing trend associated with increasing benthic production, indicating favorable environmental regime, and, together with chydorid ephippia, transient increases during the climate cooling of the LIA driven by shorter open-water season.
\end{abstract}

Keywords: autochthony; cladocera; functional ecology; organic carbon; paleolimnology; tundra lakes; UV radiation

\section{Introduction}

Impacts of recent climate warming are emphasized in small and shallow high latitude lakes being driven by higher air and water temperature and longer open-water season [1]. In a long-term perspective, these major physical drivers shift arctic and subarctic aquatic ecosystems toward an unprecedented ecological status [2,3]. Identification and characterization of the new high latitude lake trajectories is significant since they connect lake food webs, by aquatic-terrestrial coupling, to global-scale biogeochemical processes [4]. Northern ecotonal tree line lakes and their sedimentary environmental archives act as sentinels for estimating current ecosystem functioning and organization with respect to natural variability over the course of the Holocene [5].

The balance between autochthonous (in-lake produced) and allochthonous (catchment-originated) organic matter in aquatic systems is of high importance to the global carbon cycle, since lakes store and transfer carbon and act across the atmospheric-terrestrial-aquatic boundaries [4]. A common 
character of high latitude lakes is high water transparency, i.e., low amount of terrestrially derived dissolved organic matter (usually estimated as dissolved organic carbon (DOC)) due to lack or scarcity of catchment vegetation [6]. While typically systems with DOC concentrations over $5 \mu \mathrm{g} \mathrm{L}^{-1}$ are estimated to be heterotrophic [7], the high latitude lake food webs with low (approximately 1-3 $\mu \mathrm{g} \mathrm{L}^{-1}$ ) DOC are principally dependent on autochthonous production. High water transparency induces low attenuation of sunlight and UV radiation and organisms must therefore cope with high UV exposure [8]. Furthermore, food webs and secondary production may be supported primarily by benthic primary production that is fueled by the ample light [9]. However, under climate warming, i.e., due to the advancing tree line, expanding tundra vegetation or thawing permafrost, previously autochthonous and transparent lakes may experience increases in input of allochthonous organic matter from the catchment causing fundamental changes in light climate and energy pathways [5,10,11]. Alternatively, climate warming may enhance autochthony through lengthening of the open-water season and increasing habitat availability for benthic primary producers [12,13].

Knowledge of ecological and biogeochemical functions of aquatic organisms, e.g., feeding guilds, habitat preferences, and photoprotective mechanisms, is important when examining lake food webs and the organic matter cycle. Paleolimnological research focusing on long-term distribution of microscopic aquatic fossils (e.g., crustacean cladocerans or diatom algae) has slowly shifted toward biodiversity sciences [14-16] but an actual functional approach, where functional rather than taxonomic classification of fauna and flora is assessed in relation to natural and anthropogenic ecosystem variability, still remains rather rare. The functional approach may allow a holistic understanding of changes and drivers occurring in lakes and their surroundings since ecosystem functions are not dependent on taxonomic identity $[17,18]$. In addition to the use of functional diversity (FD) as an index for assessing functional trait distribution in fossil biological assemblages, functionality may be estimated, for example, by patterns in feeding, habitats, reproduction, and morphology [19-22].

In the current study, our focus was on Cladocera (Crustacea) communities and their functioning over the past millennia in a subarctic tundra lake. More specifically, we analyzed fossil cladoceran communities and functional attributes including functional diversity (FD index), reproduction patterns (Chydoridae and Bosmina fossil ephippia), and photoprotection (melanization based on carapace UV absorbance) in a 2000-yr sediment core and compared these data to previously available paleoclimate and biogeochemical proxies. The objectives were to track long-term changes in cladoceran community functioning and lake water bio-optics, and to identify interconnections of functional ecology and past climate-driven limnological changes.

\section{Materials and Methods}

Lake Loažžejávri is located in the subarctic (mean July temperature $+12.3^{\circ} \mathrm{C}$, mean annual temperature $\left.-2{ }^{\circ} \mathrm{C}\right)$ shrub tundra of Finnish Lapland $\left(69^{\circ} 53^{\prime} \mathrm{N}, 26^{\circ} 55^{\prime} \mathrm{E}\right)$ at an altitude of $255 \mathrm{~m}$ a.s.l. (Figure 1). The lake has an area of $\sim 3$ ha with a catchment size of $\sim 200$ ha and it is shallow (water depth $1.2 \mathrm{~m}$ ), oligotrophic (total phosphorus (TP) $5.9 \mu \mathrm{g} \mathrm{L}^{-1}$, chlorophyll- $a$ (chl-a) $1.6 \mu \mathrm{g} \mathrm{L}^{-1}$ ) and transparent (dissolved organic carbon (DOC) $3.4 \mathrm{mg} \mathrm{L}^{-1}$, UV attenuation coefficient at $305 \mathrm{~nm}\left(K_{\mathrm{dUV}}\right) 11.1 \mathrm{~m}^{-1}$ ). A 38-cm sediment sequence was cored from the basin in late summer 2014 with a Limnos gravity corer and subsampled at $1-\mathrm{cm}$ intervals and dated with the ${ }^{14} \mathrm{C}$ dating method. The core covers approximately the past two millennia. The lake has previously been investigated as a part of regional limnological survey [23], and its sediments for late Holocene paleoclimate [24] and carbon utilization of aquatic macroinvertebrate communities [25], from where detailed information on limnological characteristics, catchment and sedimentology, chronology, and biostratigraphy can be found. The age-depth model for the core was based on two plant macrofossils at sediment depths 20 (1390-1440 C.E.) and $25 \mathrm{~cm}$ (970-1025 C.E.) analyzed for AMS (accelerator mass spectrometry) ${ }^{14} \mathrm{C}$ dates. Additionally, ${ }^{137} \mathrm{Cs}$ and ${ }^{210} \mathrm{~Pb}$ were analyzed but their concentrations remained low and therefore insufficient to add further temporal resolution to the age-depth model [24]. 


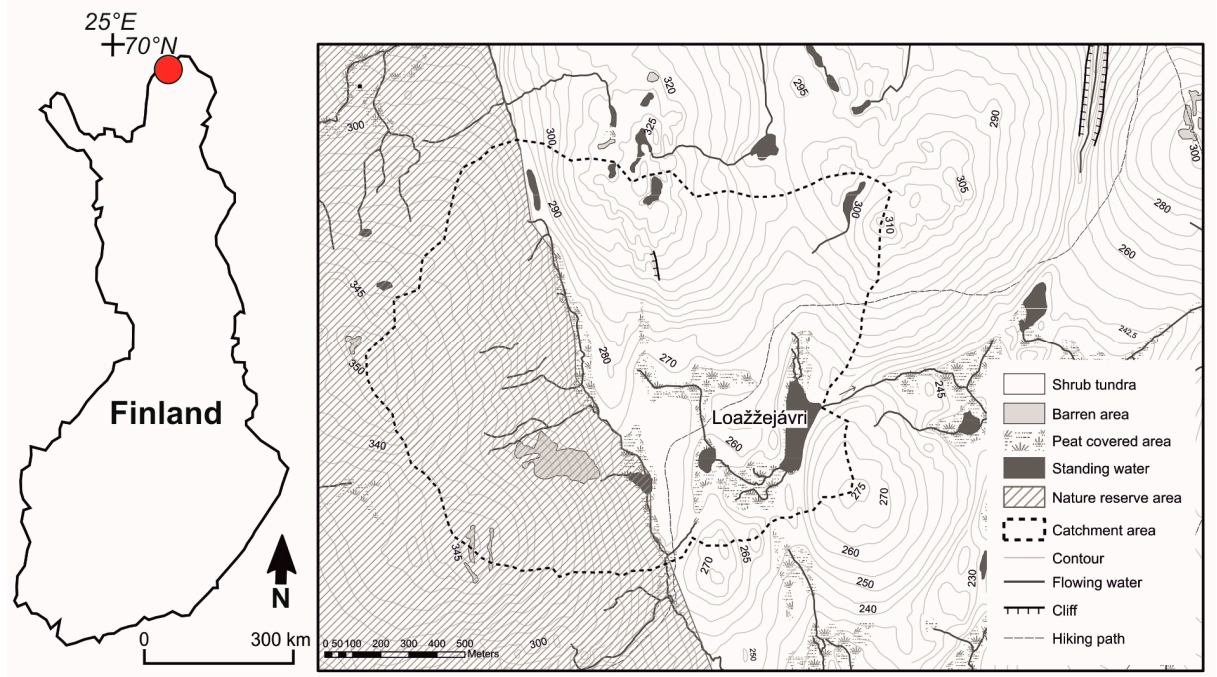

Figure 1. Location of Lake Loažžejávri in northern Finnish Lapland (red dot in left column) and its catchment characteristics (right column).

Fossil Cladocera were analyzed from the sediment subsamples (1-cm resolution) to examine past community changes. The samples were prepared by heating and stirring $\sim 2 \mathrm{~cm}^{3}$ of fresh sediment in $10 \%$ potassium hydroxide ( $\mathrm{KOH}$ on a hot plate following the standard protocol [26]. The samples were then sieved through a 51- $\mu \mathrm{m}$ mesh and the residues were centrifuged for $10 \mathrm{~min}$ at $4000 \mathrm{rpm}$. Permanent microscope samples were mounted in glycerol gelatin stained with safranine on a hot plate. The micropscope slides were examined for fossil cladoceran remains (carapaces, head shields, postabdomens, claws, ephippia) with a light microscope at $100-400 \times$ magnifications and a minimum of 70 individuals were identified [27] from each sample (53 individuals from sample at $3 \mathrm{~cm}$ due to low amount of remains).

In addition to standard community analysis described above, functional attributes of sexual reproduction, functional diversity, and melanization were analyzed. Total bosminid (Bosminidae, Bosmina) and chydorid (Chydoridae) ephippia (chitinous envelops for diapausal resting eggs, indicative of sexual reproduction) were enumerated during the standard counting and were used for estimates of sexual reproduction (ratio of sexual to asexual reproduction) by enumerating Bosmina and chydorid ephippia (indicative of sexual reproduction) and carapaces (indicative of asexual reproduction) [28]. Functional diversity of the cladoceran community was expressed as Rao's FD index, i.e., Rao's quadratic entropy [29]. For this index, each fossil cladoceran taxa was assigned with selected qualitative functional characters (traits, Table 1) including body size (small $<500 \mu \mathrm{m}$, intermediate $500-1000 \mu \mathrm{m}$, large $>1000 \mu \mathrm{m}$ ), body shape (elongated, oval, globular), feeding type (filterer, scraper-detritivore, predator) and habitat (pelagic, benthic, attached to vegetation) following [21]. To examine melanin in cladoceran remains as an index for UV exposure and photoprotection [30], fossil cladoceran carapaces from a large chydorid species Alona affinis (Leydig) were extracted from sediment subsamples with fine forceps under a binocular microscope. The carapaces were then measured under UV wavelengths 340 and $305 \mathrm{~nm}$ for their $\mathrm{UV}$ absorbance $\left(\mathrm{ABS}_{\mathrm{UV}}\right)$ to indicate the degree of melanization. The absorbance measurements were performed with a UV/VIS spectrophotometer (UV-1800, Shimadzu Corporation, Kyoto, Japan). Seven carapaces were measured for a mean UV absorbance value per sample omitting highest and lowest absorbance values. UV absorbance measurements are expressed as anomalies from the mean absorbance value of the data series.

The data were further analyzed with numerical methods to elucidate relationships between cladoceran community and functional attributes and paleoenvironmental variation. Redundancy analysis (RDA) was utilized to examine impacts of sediment biogeochemistry (indicative of habitat quality), i.e., elemental and isotopic composition $\left(\mathrm{C} \%, \mathrm{~N} \%, \mathrm{C} / \mathrm{N}\right.$ ratio, $\delta^{13} \mathrm{C}$, and $\left.\delta^{15} \mathrm{~N}\right)$ and amount of organic matter $(\mathrm{OM} \%$, data from [25]), on cladoceran community succession though time. In addition, 
external atmospheric forcers, i.e., sun spot numbers (SSN) and summer (June-August) air temperature (T-JJA) as 10-year averages [following 31,32, respectively] were used in the RDA as environmental factors. SSN reconstruction is based on dendrochronologically dated radiocarbon concentrations and physics-based models [31] and T-JJA reconstruction is based on maximum latewood density tree-ring chronologies [32]. Species data were square-root transformed prior to data analyses. Paleoenvironmental parameters with high inflation factors were omitted to include a set of variables with inflation factors $<10\left(\mathrm{C} / \mathrm{N}, \delta^{13} \mathrm{C}, \delta^{15} \mathrm{~N}, \mathrm{OM} \%\right.$, SSN, T-JJA). Forward selection of environmental parameters was performed with 999 permutations and significant parameters were assigned as $p<0.05$. Selected bivariate environmental correlations for functional attributes were examined with Pearson's correlation coefficient and linear regression. RDA was performed with Canoco 5 software [33] and linear regressions with PAST3 software [34]. In addition to $\mathrm{OM} \%$, organic matter $\delta^{13} \mathrm{C}$, and SSN, mean carbon source contributions in the benthic food web (based on fossil Chironomidae $\delta^{13} \mathrm{C}$ ), modeled with a three-source (benthic, planktonic, and terrestrial) Bayesian mixing model previously applied in [22], were utilized as paleoenvironmental reference data. Here, the modeled planktonic and benthic carbon contributions (to Chironomidae diet) were used in a planktonic to benthic $(\mathrm{P} / \mathrm{B})$ ratio. Further, autochthonous (planktonic + benthic) and allochthonous (terrestrial) carbon sources were used in autochthonous to allochthonous ratio. These ratios were calculated based on the Chironomidae $\delta^{13} \mathrm{C}$ based source data [25].

Table 1. Functional traits of cladoceran taxa encountered from Lake Loažžejávri sediment core. Characterization is based on body size $(\mathrm{S}=$ small, $\mathrm{M}=$ intermediate, $\mathrm{L}=$ large $)$, body shape $(\mathrm{G}=$ globular, $\mathrm{O}=$ oval, $\mathrm{E}=$ elongated $)$, feeding $(\mathrm{F}=$ filterer, $\mathrm{S}-\mathrm{D}=$ scraper-detritivore, $\mathrm{P}=$ predator, including parasitism), and habitat $(\mathrm{P}=$ pelagial, $\mathrm{S}=$ sediment, $\mathrm{V}=$ vegetation $)$.

\begin{tabular}{|c|c|c|c|c|c|c|c|c|c|c|c|c|}
\hline & \multicolumn{3}{|c|}{ Body Size } & \multicolumn{3}{|c|}{ Body Shape } & \multicolumn{3}{|c|}{ Feeding } & \multicolumn{3}{|c|}{ Habitat } \\
\hline & $\mathrm{S}$ & $\mathbf{M}$ & $\mathbf{L}$ & G & $\mathbf{O}$ & $\mathbf{E}$ & F & S-D & $\mathbf{P}$ & $\mathbf{P}$ & $\mathbf{S}$ & $\mathbf{V}$ \\
\hline Bosmina longispina & & * & & $*$ & & & * & & & * & & \\
\hline Daphnia spp. & & & * & & * & & * & & & * & & \\
\hline Ceriodaphnia spp. & & * & & & * & & * & & & * & & * \\
\hline Polyphemus pediculus & & & $*$ & & & $*$ & & & * & $*$ & & \\
\hline Bythotrephes longimanus & & & $*$ & & & * & & & * & $*$ & & \\
\hline Simocephalus spp. & & & * & & * & & * & & & & & * \\
\hline Ophryoxus gracilis & & & $*$ & & $*$ & & * & * & & & $*$ & * \\
\hline Eyrycercus spp. & & & $*$ & & $*$ & & & * & & & * & * \\
\hline Camptocercus rectirostris & & & $*$ & & * & & & * & & & * & * \\
\hline Acroperus harpae & & * & & & * & & & * & & & * & * \\
\hline Alonopsis elongata & & * & & & * & & & * & & & * & \\
\hline Graptoleberis testudinaria & & * & & & $*$ & & & * & & & & * \\
\hline Alona affinis & & * & & & * & & & * & & & * & * \\
\hline Alona quadrangularis & & * & & & $*$ & & & * & & & * & \\
\hline Alona guttata & $*$ & & & & $*$ & & & * & & & * & * \\
\hline Alona guttata f. tuberculata & $*$ & & & & * & & & * & & & * & * \\
\hline Alona rustica & & * & & & * & & & * & & & * & * \\
\hline Alona intermedia & $*$ & & & & * & & & * & & & * & * \\
\hline Alona werestschagini & & * & & & $*$ & & & * & & & * & \\
\hline Alonella excisa & $*$ & & & * & & & & * & & & * & * \\
\hline Alonella nana & * & & & * & & & & * & & & * & * \\
\hline Chydorus sphaericus-type & $*$ & & & * & & & & * & & $*$ & & * \\
\hline Paralona pigra & * & & & * & & & & * & & & * & \\
\hline Rhynchotalona falcata & * & & & & * & & & * & & & * & \\
\hline Drepanothrix dentata & & * & & & $*$ & & & * & & & * & \\
\hline Iliocryptus spp. & & & * & & $*$ & & & * & & & * & \\
\hline Anchistropus emarginatus & & * & & * & & & & & * & & * & * \\
\hline
\end{tabular}




\section{Results}

A total of 27 cladoceran taxa were identified from the sediment subsamples. The most frequent taxa (occurring in every subsample) included Alonella nana (Hill's N2 36.5, mean relative abundance 42.5\%), Bosmina longispina (36.4, 32.5\%), Alona affinis (34.5, 7.9\%), Chydorus sphaericus-type (24.3, 6.1\%), and Paralona pigra (25.1, 1.5\%). In the cladoceran stratigraphy (Figure 2), B. longispina and A. affinis dominated with $\sim 20 \%-60 \%$ abundances throughout the sediment sequence, B. longispina peaking between 1400 and 1500 C.E. and A. nana between 1600 and 1800 C.E. Many littoral-benthic taxa, including C. sphaericus-type, Acroperus harpae, Alonella excisa, and Eurycercus spp. increased slightly during 600-1200 C.E. and others, including Alona quadrangularis and A. guttata, increased or emerged at the top sequence after 1600 C.E.

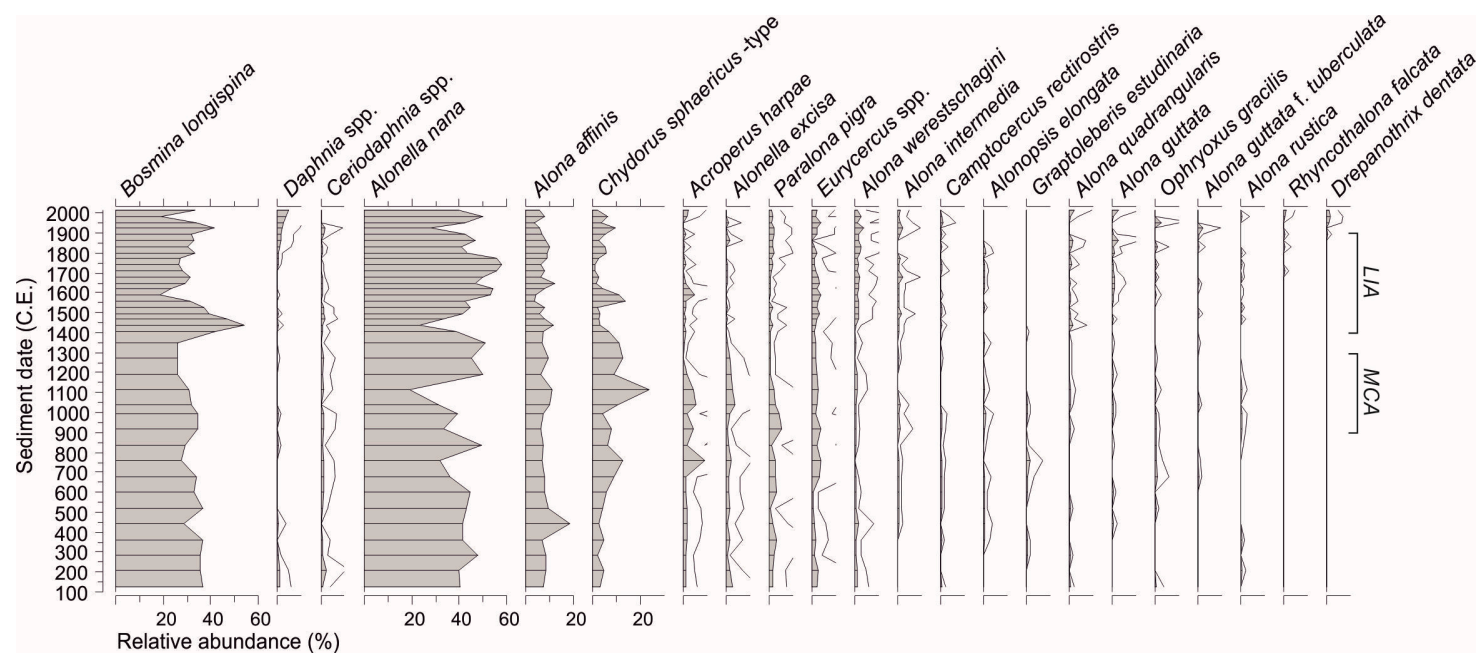

Figure 2. Relative abundance of most common (Hill's N2 > 3.5) cladoceran taxa in the Loažžejávri sediment core indicated with a gray silhouette, where black horizontal lines represent sediment sub-samples. Five-fold exaggeration curves of less abundant taxa are shown with gray lines. Temporal extensions of the cold Little Ice Age (LIA) and warm Medieval Climate Anomaly (MCA) are approximated.

RDA and forward selection of environmental variables resulted in eigenvalues of 0.14 and 0.07 for axes 1 and 2, respectively, explaining 35.2\% of variation in species data (Figure 3). It identified $\delta^{13} \mathrm{C}$ $(41.7 \%, \mathrm{~F}=6.2, p<0.001), \mathrm{OM} \%(20.1 \%, \mathrm{~F}=3.2, p<0.001)$, and SSN $(11.5 \%, \mathrm{~F}=1.9, p=0.035)$ as the most significant environmental parameters explaining variation in cladoceran species data, together accounting for $73.3 \%$ of the explained variation. Most recent samples (12-0 cm, 1650 C.E.- present) had positive axis 1 scores in relation to increasing $\delta^{13} \mathrm{C}, \mathrm{OM} \%$ and SSN. Alonella nana, Alona werestschagini, Alona quadrangularis, and Alona guttata were associated with increasing $\delta^{13} \mathrm{C}$. Rhynchotalona falcata, Drepanothrix dentata, Alona intermedia, and Daphnia spp. were associated with increasing OM\% and SSN having more positive scores for RDA axis 2. Older than 1650 C.E. samples had negative axis 1 scores and the abundant taxa, such as Bosmina longispina and Chydorus sphaericus-type, and vegetation-associated taxa Alonella excisa, Acroperus harpae, and Eurycercus spp. were related to the negative end of RDA axis 1 (i.e., low $\delta^{13} \mathrm{C}$ ).

Of the cladoceran-based functional indices (Figure 4), chydorid and Bosmina sexual reproduction both increased around 700-800 C.E. and peaked later on during 1400, 1800, and 1900 (chydorids) and 1300 (Bosmina) C.E., after which Bosmina sexual reproduction declined. Minimum values occurred around 1700 and 1900 C.E. in chydorids and Bosmina, respectively. Mean abundance of chydorid and Bosmina ephippia encountered in the samples was high, 33 (min. 6, max. 65) and 18 (min. 1, max. 50) ephippia, respectively. Cladoceran FD was highly variable, but exhibited increases during

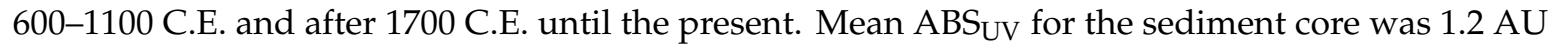


(absorbance units). $\mathrm{ABS}_{\mathrm{UV}}$ exhibited several peaks, indicative of more intensive melanization (i.e., higher UV exposure) during the early core at $\sim 300,600$, and 1000 C.E. and in the younger layers $\sim 1500$ and 1700-1800 C.E.

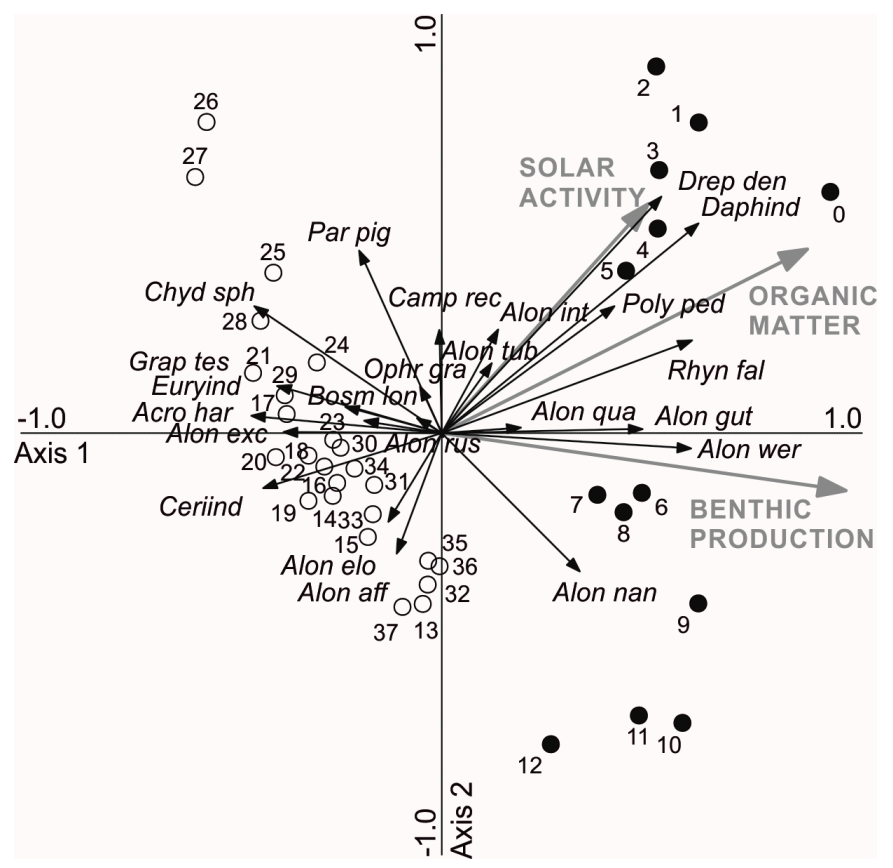

Figure 3. Redundancy analysis ordination diagram for the cladoceran taxa and samples in relation to significant environmental variables $\delta^{13} \mathrm{C}$ of sediment organic matter (benthic production), organic matter content (as loss-on-ignition), and solar activity (as reconstructed sun spot numbers). Pre 1650 C.E. samples $(13-37 \mathrm{~cm})$ are indicated by white dots and the recent samples $(0-12 \mathrm{~cm})$ by black dots. Data for sediment geochemistry are from [25] and for solar activity from [30]. Species abbreviations include four letters of the genus and three from the species name.

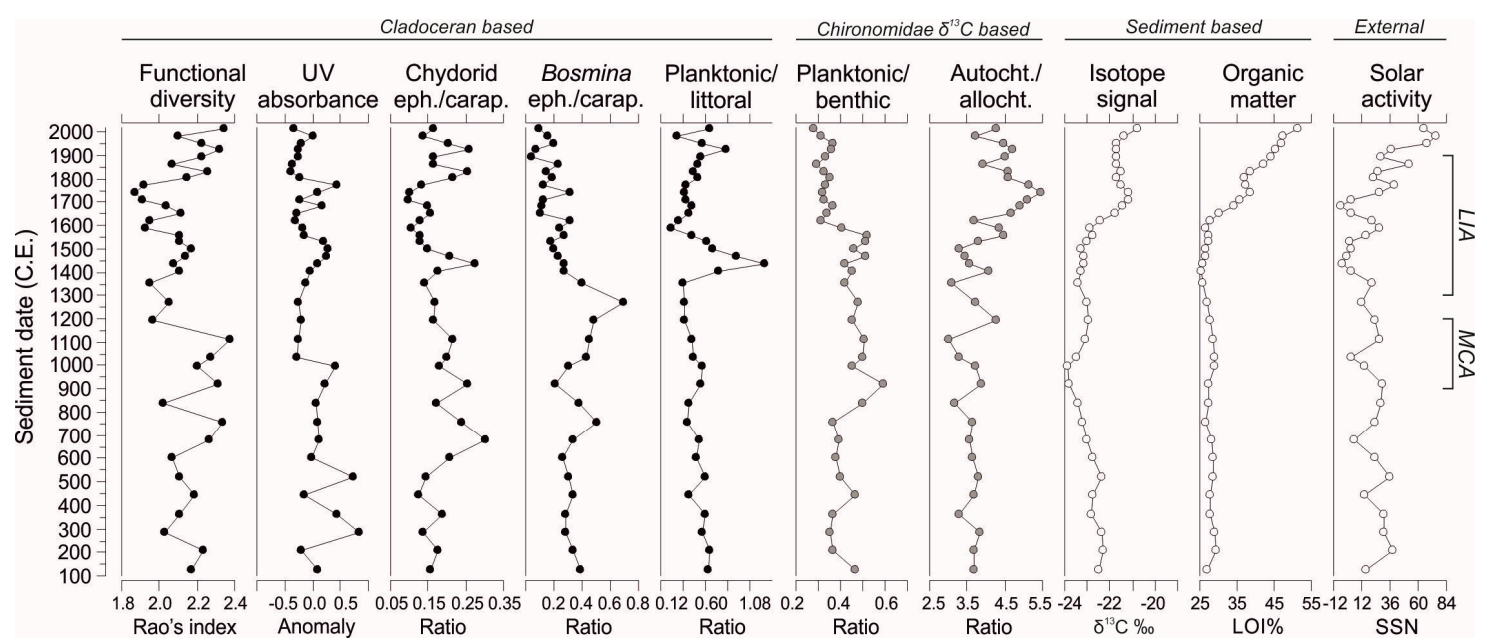

Figure 4. Cladoceran based functional attributes; functional diversity, UV absorbance of Alona carapaces, ratio of ephippia (sexual reproduction) to carapaces (asexual reproduction) of Chydoridae and Bosmina, and cladoceran planktonic to littoral ratio. In addition, ratios of mean source contributions (planktonic to benthic and autochthonous to allochthonous) in the benthic food web (based on Chironomidae $\delta^{13} \mathrm{C}$ and Bayesian mixing modeling), sediment organic matter $\delta^{13} \mathrm{C}$, organic matter content (as loss-on-ignition), and solar intensity (as reconstructed sun spot numbers) are shown. Data for sediment geochemistry and source contributions are after [25] and for solar intensity after [31]. Temporal extensions of the cold Little Ice Age (LIA) and warm Medieval Climate Anomaly (MCA) are approximated. 
Significant Pearson's correlations were found between T-JJA and FD ( $\mathrm{r}=0.48, p=0.002$; Figure 5a), sediment $\mathrm{C} / \mathrm{N}$ ratio and carapace $\mathrm{UV}$ absorbance $(\mathrm{r}=0.46, p=0.004$; Figure $5 \mathrm{~b})$, and sediment carbon content and Bosmina ephippia/carapaces ratio ( $\mathrm{r}=-0.60, p=<0.001$; Figure $5 \mathrm{c})$. In addition, $\mathrm{ABS}_{\mathrm{UV}}$ had significant $(p=<0.05)$ correlations with $\mathrm{C} \%(\mathrm{r}=-0.37)$ and $\mathrm{N} \%(\mathrm{r}=-0.33)$ and Bosmina ephippia with $\mathrm{N} \%(\mathrm{r}=-0.56), \mathrm{C} / \mathrm{N}(\mathrm{r}=0.32), \delta^{13} \mathrm{C}(\mathrm{r}=-0.59), \delta 15 \mathrm{~N}(\mathrm{r}=0.64)$, and $\mathrm{OM} \%(\mathrm{r}=-0.59)$.
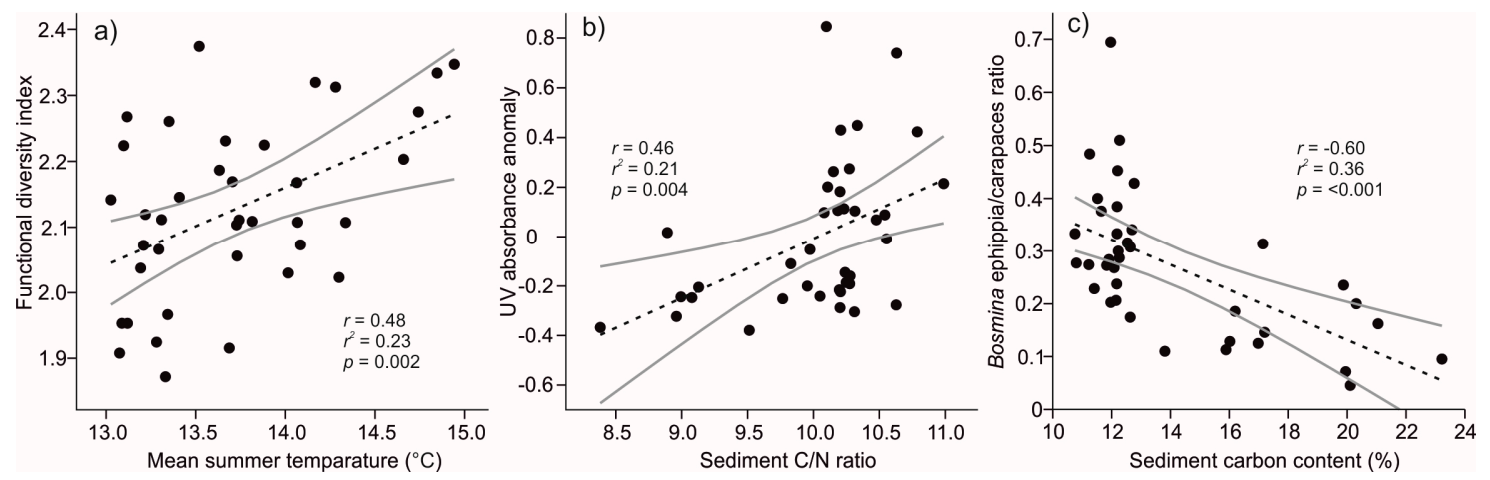

Figure 5. Bivariate relationships ( $r=$ Pearson's correlation, $r^{2}=$ coefficient of determination in linear regressions, $p=$ significance) of (a) cladoceran functional diversity and reconstructed summer (June-August) mean temperature, (b) carapace UV absorbance anomaly and sediment carbon to nitrogen ratio $(\mathrm{C} / \mathrm{N})$, and (c) ratio of ephippia (sexual reproduction) to carapaces (asexual reproduction) in Bosmina and sediment carbon content. Black dots represent sediment core subsamples, black dashed lines indicate linear regression models and gray lines 95\% confidence intervals. Sediment geochemical data originates from [25] and summer mean temperature reconstruction from [32].

\section{Discussion}

\subsection{Lake Functioning}

While recent research has highlighted the role of northern waters in the cycling of terrestrial organic matter, there also exists contrasting evidence suggesting insignificant contribution of terrestrial inputs to aquatic systems [35-37]. For example, a trend of increasing autochthony rather than allochthony has been observed in small lakes from northern Finnish Lapland [13,25]. Benthic autochthonous production prevailed in Lake Loažžejávri over the past two millennia supporting aquatic consumers such as macrobenthic Chironomidae (chironomid) larvae [24,25]. Of the autochthonous organic material consumed, planktonic carbon component, inferred and modeled from $\delta^{13} \mathrm{C}$ of chironomid head capsules, was slightly elevated (increase in P/B, Figure 4) during the warm Medieval Climate Anomaly (MCA) at around 900-1300 C.E. This increase is likely indicative of higher algal production and its more efficient utilization by consumers [25]. Benthic production and benthic carbon component in chironomid diet (inferred from $\delta^{13} \mathrm{C}$ of chironomid head capsules) clearly dominated in the lake after $\sim 1600$ C.E. and may have been a reflection of reduced ice-cover period after the LIA climax creating wider benthic niche space for autotrophic organisms generally increasing the relative importance of the benthic habitat over the pelagic one [38].

The production in the lake being mostly benthic, the main driver for long-term cladoceran community shifts in Lake Loažžejávri sediment profile was related to the benthic habitat quality. According to the RDA, $\delta^{13} \mathrm{C}$ signature indicating the origin of organic matter, i.e., autochthonous (planktonic or benthic) or allochthonous, was the most significant environmental parameter explaining cladoceran assemblages (Figure 3). The isotopic carbon signature separated the sediment core subsamples along the RDA axis 1 to pre- and post-1650 C.E. sample clusters (Figure 3). Organic matter $\delta^{13} \mathrm{C}$ varied relatively little during the first 1500 years of the sequence but started to increase at $\sim 1600$ C.E. indicative of more pronounced benthic primary production [25]. In concert, the cladoceran community diversified with the inclusion and increase of several benthic taxa, e.g., Alona werestschagini, A. quadrangularis, A.guttata, R.falcata, and Drepanothrix dentata until the 21st century (Figure2). Chydorid 
benthos has been shown to utilize unselectively periphyton and detritus for food in similar lake environments in the region [13] and the assemblage change was thus likely driven by a diversification of microhabitats among the benthic vegetative substrata [39]. Alternatively, the diversification of the benthic habitats may have allowed species with more specialized feeding strategies to increase in the lake following the benthic succession. In common, consistent increases of specialized cladoceran taxa in relation to climate warming have been reported from arctic Canada [40].

Despite its shallowness, the lake supported a planktonic food web, as evidenced by the high abundance of euplanktonic Bosmina longispina, presence of Ceriodaphnia, and scattered occurrence of Daphnia throughout the core (Figure 2) as well as presence of some free living Chironomidae (Ablabesmya and Procladius, [24]). In the current results, Bosmina was associated with more negative $\delta^{13} \mathrm{C}$ values of organic matter (Figure 3), indicative of an association with phytoplankton production. Bosmina is known to feed selectively on phytoplankton in small and shallow lakes in northern Finland [13,41]. In contrast to Bosmina, some planktonic cladocerans, e.g., Daphnia and Ceriodaphnia may assimilate benthic food particles grazing directly over the sediment microbial active layer [9]. In the RDA, Daphnia was associated with elevated $\delta^{13} \mathrm{C}$ of organic matter suggesting a connection with the benthic production. Related to the shift in autochthonous production (i.e., increase in benthic production), Bosmina decreased slightly but still remained as the dominant planktonic taxon, while Daphnia increased at the top of the sediment core (Figure 2). Accordingly, it is possible that the establishment and increase of Daphnia 1850 C.E. onward was related to its ability to utilize benthic resources [42]. In all, planktonic cladocerans, B. longispina as the governing taxon, showed rather constant presence in the sediment sequence aside from a transient increase at $\sim 1400$ C.E. (Figure 2 ) This abrupt event was likely associated with a short-term ( 100 years) hydroclimatic event of the early Little Ice Age (LIA) causing higher lake level and relative increase of the planktonic habitat.

Despite the shift toward benthic production, Bosmina showed high resilience [41] as it remained abundant up to the surface (Figure 2). Though, a change in its reproduction occurred with a decreasing trend in sexual reproduction after a peak around 1300 C.E. suggesting less environmental stress (lower sexual reproduction) during the recent centuries. Sexual reproduction in Cladocera is evidenced in the fossil record through their ephippia and has previously been investigated in relation to climate oscillation, i.e., open-water season length, which dictates the relative importance of asexual (parthenogenetic) vs. sexual (gamogenetic) reproduction [28,43]. Accordingly, it has been suggested that sexual reproduction is less significant (lower sexual reproduction) during warm climate conditions as asexual reproduction prevails under long open-water season. As cold climate of the LIA started to prevail in northern Finland already during the 15th century, the long-term trend in Bosmina reproduction was not apparently strictly dictated by open-water season length but also other environmental stimuli counteracted in the reproduction patterns. Bosmina sex ratios had a strong negative relationship with sediment carbon content (and organic matter content, Figure 5c) possibly indicative of the past low productive conditions (i.e., low sediment carbon content) being more unfavorable to Bosmina than the new, i.e., post-1650 C.E., regime with increasing benthic autotochthonous production. Chydorid sexual reproduction increased during the 15th century, and later peaks 1800 and 1900, that were likely attributable to reduced length of the open-water season driven by cold climate events of the LIA $[44,45]$.

FD combines the observations of biodiversity and ecological functions to detect trends and patterns in ecosystem functions $[17,46]$. In the current study, cladoceran FD was generally lower during the early core and between 1200 and 1800 C.E. and higher between 900 and 1200 C.E. and in the top sequence, from 1850 onward (Figure 4). The pristine Lake Loažžejávri is mostly governed by natural forcers such as climate due to its remote location in the tundra [25] and, in agreement, there existed a positive relationship between FD and reconstructed T-JJA (Figure 5a) as FD was higher during the MCA and during the post-LIA climate warming (Figure 4). Based on previous paleoecological records [21,47], it has been suggested that long-term development of cladoceran FD is connected with lake productivity, although dependent on the size and eutrophication history of the system in question. We did not find 
any statistical relationships between FD and biogeochemical proxies related to productivity but the established relationship between FD and T-JJA likely reflects the ultimate climatic (i.e., temperature) control on habitat development and productivity in this cold tundra environment through dictating the length of ice-cover period [48].

\subsection{Paleo-Optics}

Natural variability in light and UV attenuation in forest and tundra lakes may be strongly related to coupling processes with temperature and precipitation via surrounding vegetation and permafrost $[5,30]$. However, in aquatic systems located on barren catchments terrestrial inputs of UV screening compounds are low and autochthonous organic matter, e.g., algal biomass acts as an important component in UV attenuation [49]. The tundra catchment of Lake Loažžejávri is currently covered with only $\sim 5 \%$ of wetlands [23] but the lake shore is directly connected with paludified shorelines and water channels up in the nested drainage basin (Figure 1). Even though Loažžejávri features low lake water DOC $\left(3.4 \mathrm{mg} \mathrm{L}^{-1}\right)$ and chl-a $\left(1.6 \mu \mathrm{g} \mathrm{L}^{-1}\right)$, it has been estimated that only a few percent of UV penetrates below $0.5 \mathrm{~m}$ water depth [50]. However, the shallow littoral and benthic habitats of the lake are exposed to UV and aquatic biota are thus likely to respond to UV. The ABS $\mathrm{UV}$ record of Loažžejávri, indicating melanization and past UV exposure of the benthic Alona, was highly variable in the past suggesting large natural variations in underwater UV regimes (Figure 4).

In arctic and subarctic lakes, long-term changes in UV exposure have been mostly governed directly, or indirectly through photodegradation of OM, by solar radiation intensity [51-53]. Although solar forcing interacted partly in cladoceran assemblage succession, SSN reconstruction explaining $\sim 12 \%$ of the species variation (Figure 3 ), it did not have substantial association with the current ABS UV $_{\text {V }}$ record (Figure 4). In an adjacent lake, which differed from Loažžejávri by its location in the mountain birch woodland at a lower altitude, millennial variation in $\mathrm{ABS}_{\mathrm{UV}}$ was in clear connection with solar intensity [13,53]. In Loažžejávri, highest carapace ABS $U$ v was recorded in the early core ( 300 and 500 C.E.) and later on during 1400-1500 and 1700-1800 C.E. The high variability of ABS $_{U V}$ in the early core does not seem to clearly correlate with changes in SSN reconstruction, sediment geochemistry or cladoceran communities (Figures 2 and 4). However, the latter ABS $\mathrm{UV}$ peaks were likely related to a more transparent water column during the LIA, related to constrained organic matter flux from the catchment and reduced in-lake production driven by longer ice-cover period. A similar pattern of increased aquatic UV exposure during the LIA has occurred in lakes of northern and eastern Finland and in the Alps [30,53]. The pre MCA period at the middle of the first millennium of the Common Era has been characterized to be hydroclimatically dry in Fennoscandia. This period overlaps with the Dark Ages Cold Period characterized by noticeable climatic fluctuations [54,55], that may have been driving the early fluctuations in $\mathrm{ABS}_{U V}$ (higher peaks 300 and 500 C.E.) through climate-driven catchment coupling.

There existed a conspicuous long-term relationship between sediment $\mathrm{C} / \mathrm{N}$ ratio and $\mathrm{ABS} \mathrm{SV}_{\mathrm{UV}}$ indicating lower UV exposure under increasing autochthony (Figure 5b). This result contradicts a previous investigation from a regional lake set across the subarctic tree line suggesting an intrinsic control of terrestrial DOM (wetland origin) on underwater UV exposure and carapace UV absorbance [50]. As said, Lake Loažžejávri is located on a barren tundra catchment with little terrestrial organic matter contribution throughout its examined history, although connected with some wetland impact [18]. Since $\mathrm{ABS}_{U V}$ was lower under prevalently autochthonous conditions, it is possible that UV screening properties of phytoplankton, or specifically those of phytobenthos in this benthic dominated system, have impacted carapace melanization of the benthic Alona. In subarctic and arctic lakes, benthic phototrophic communities, including cyanobacteria, algae, and hetero- and chemoautotrophic micro-organisms grow to form thick and stratified biofilms or mats [56], which support benthic and pelagic secondary production and bacterial planktonic production [57,58]. As such, these massive biofilms may act as physical UV refugia for benthic invertebrates allowing them to crawl deeper into the shelter of the mat, since top layers of the benthic mats are abundant in algal pigments 
screening UV $[59,60]$. At the same time as acting as a UV screen, the benthic mats likely provided fertile grazing surface for the microbenthos. It has been suggested previously that UV responses of shallow water benthic communities are principally driven by their access to physical UV refugia [61]. Accordingly, we propose that the generally lower carapace UV absorbance values in the top of the core, with the exception of the two high peaks apparently related to the LIA, were caused by increased benthic autochthonous production providing a physical UV shelter for benthic invertebrates.

\section{Conclusions}

Climatic fluctuations of the cold Little Ice Age and after were seen in the studied tundra lake as increases in benthic autochthonous production due to reduction in the length of ice-cover period. This centennial ecosystem scale succession toward dominance of benthic production has altered community structure, induced higher functional diversity, promoted relative importance of asexual reproduction, and reduced UV exposure in cladocerans. Main ecological mechanisms were related to diversification of benthic niche space, likely as a development of benthic microbial mats.

Fossil cladoceran communities in the studied tundra lake, consisting of planktonic and benthic species, seem to have been relatively resilient to climatic fluctuations until their habitat structure was disturbed. Periodically highly abundant sexual reproduction as a way for dormancy or better fitness (genotypic variation) has likely contributed to cladoceran community resilience. The diversification of the benthic niches induced functionally richer cladoceran communities including the keystone planktonic grazer Daphnia and specialized benthic species suggesting that functional diversity is coupled with lake productivity. In addition, the establishment of benthic mats likely provided physical UV refugia for benthic cladocerans emphasizing the fundamental importance of habitat quality for these microinvertebrates.

Author Contributions: Conceptualization, L.N. and E.H.K.; methodology, L.N., E.H.K., M.V.R. and T.P.L.; software, L.N.; validation, L.N., E.H.K., M.V.R. and T.P.L.; formal analysis, L.N.; investigation, L.N.; resources, L.N.; data curation, L.N.; writing-original draft preparation, L.N.; writing-review and editing, E.H.K., M.V.R. and T.P.L.; visualization, L.N. and E.H.K.; supervision, L.N.; project administration, L.N., E.H.K. and M.V.R.; funding acquisition, L.N.

Funding: This research was funded by Academy of Finland, grant number 287547 (VIOLET-project) and $308954+$ 314107 (SCUM-project).

Acknowledgments: Annukka Galkin and staff of the Kevo Subarctic Research Station are thanked for assistance with the field work. We thank two anonymous reviewers for their constructive comments.

Conflicts of Interest: The authors declare no conflict of interest.

\section{References}

1. Smol, J.P. Arctic and Sub-Arctic shallow lakes in a multiple-stressor world: A paleoecological perspective. Hydrobiologia 2016, 778, 253-272. [CrossRef]

2. Smol, J.P.; Wolfe, A.P.; Birks, H.J.B.; Douglas, M.S.; Jones, V.J.; Korhola, A.; Pienitz, R.; Rühland, K.; Sorvari, S.; Antoniades, D.; et al. Climate-driven regime shifts in the biological communities of arctic lakes. Proc. Nat. Acad. Sci. USA 2005, 102, 4397-4402. [CrossRef] [PubMed]

3. Taranu, Z.E.; Gregory-Eaves, I.; Leavitt, P.R.; Bunting, L.; Buchaca, T.; Catalan, J.; Domaizon, I.; Guilizzoni, P.; Lami, A.; McGowan, S.; et al. Acceleration of cyanobacterial dominance in north temperate-subarctic lakes during the Anthropocene. Ecol. Lett. 2015, 18, 375-384. [CrossRef] [PubMed]

4. Cole, J.J.; Prairie, Y.T.; Caraco, N.F.; McDowell, W.H.; Tranvik, L.J.; Striegl, R.G.; Duarte, C.M.; Kortelainen, P.; Downing, J.A.; Middelburg, J.J.; et al. Plumbing the global carbon cycle: Integrating inland waters into the terrestrial carbon budget. Ecosystems 2007, 10, 172-185. [CrossRef]

5. Pienitz, R.; Vincent, W.F. Effect of climate change relative to ozone depletion on UV exposure in subarctic lakes. Nature 2000, 404, 484-487. [CrossRef] [PubMed]

6. Sobek, S.; Tranvik, L.J.; Prairie, Y.T.; Kortelainen, P.; Cole, J.J. Patterns and regulation of dissolved organic carbon: An analysis of 7500 widely distributed lakes. Limnol. Oceanogr. 2007, 52, 1208-1219. [CrossRef] 
7. Jansson, M.; Bergström, A.; Blomqvist, P.; Drakare, S. Allochthonous organic carbon and phytoplankton/ bacterioplankton production relationships in lakes. Ecology 2000, 81, 3250-3255. [CrossRef]

8. Rautio, M.; Bonilla, S.; Vincent, W.F. UV photoprotectants in arctic zooplankton. Aquat. Biol. 2009, 7, 93-105. [CrossRef]

9. Rautio, M.; Vincent, W.F. Benthic and pelagic food resources for zooplankton in shallow high-latitude lakes and ponds. Freshw. Biol. 2006, 51, 1038-1052. [CrossRef]

10. Frey, K.E.; Smith, L.C. Amplified carbon release from vast west Siberian peatlands by 2100. Geophys. Res. Lett. 2005, 32, L09401. [CrossRef]

11. Vonk, J.E.; Tank, S.E.; Bowden, W.B.; Laurion, I.; Vincent, W.F.; Alekseychik, P.; Amyot, M.; Billet, M.F.; Canário, J.; Cory, R.M.; et al. Reviews and syntheses: Effects of permafrost thaw on Arctic aquatic ecosystems. Biogeosciences 2015, 12, 7129-7167. [CrossRef]

12. Michelutti, N.; Wolfe, A.P.; Vinebrooke, R.D.; Rivard, B.; Briner, J.P. Recent primary production increases in arctic lakes. Geophys. Res. Lett. 2005, 32, L19715. [CrossRef]

13. Rantala, M.V.; Luoto, T.P.; Nevalainen, L. Temperature controls organic carbon sequestration in a subarctic lake. Sci. Rep. 2016, 6, 34780. [CrossRef] [PubMed]

14. Gregory-Eaves, I.; Beisner, B.E. Palaeolimnological insights for biodiversity science: An emerging field. Freshw. Biol. 2011, 56, 2653-2661. [CrossRef]

15. Froyd, C.A.; Willis, K.A. Emerging issues in biodiversity \& conservation management: The need for a palaeoecological perspective. Quat. Sci. Rev. 2008, 27, 1723-1732.

16. Helmens, K.F.; Katrantsiotis, C.; Salonen, J.S.; Shala, S.; Bos, J.A.A.; Engels, S.; Kuosmanen, N.; Luoto, T.P.; Väliranta, M.; Luoto, M.; et al. Warm summers and rich biotic communities during N-Hemisphere deglaciation. Glob. Planet. Chang. 2018, 167, 61-73. [CrossRef]

17. Barnett, A.J.; Finlay, K.; Beisner, B.E. Functional diversity of crustacean zooplankton communities: Towards a trait-based classification. Freshw. Biol. 2007, 52, 796-813. [CrossRef]

18. Kivilä, E.H. Functional Paleoecology and Allochthonous Inputs in High Latitude Lake Food Webs. Ph.D. Thesis, University of Jyväskylä, Jyväskylä, Finland, 2019. Available online: https://jyx.jyu.fi/handle/123456789/ 63530 (accessed on 27 September 2019).

19. Luoto, T.P.; Nevalainen, L. Climate-forced patterns in midge feeding guilds. Hydrobiologia 2015, 742, 141-152. [CrossRef]

20. Nevalainen, L.; Kivilä, E.H.; Luoto, T.P. Biogeochemical shifts in hydrologically divergent taiga lakes in response to late Holocene climate fluctuations. Biogeochemistry 2016, 128, 201-215. [CrossRef]

21. Nevalainen, L.; Luoto, T.P. Relationship between cladoceran (Crustacea) functional diversity and lake trophic gradients. Funct. Ecol. 2017, 31, 488-498. [CrossRef]

22. Kivilä, E.H.; Luoto, T.P.; Rantala, M.V.; Kiljunen, M.; Rautio, M.; Nevalainen, L. Environmental controls on benthic food web functions and carbon resource use in subarctic lakes. Freshw. Biol. 2019, 64, 643-658. [CrossRef]

23. Rantala, M.V.; Nevalainen, L.; Rautio, M.; Galkin, A.; Luoto, T.P. Sources and controls of organic carbon in lakes across the subarctic treeline. Biogeochemistry 2016, 129, 235-253. [CrossRef]

24. Luoto, T.P.; Kivilä, E.H.; Rantala, M.V.; Nevalainen, L. Characterization of the Medieval Climate Anomaly, Little Ice Age and recent warming in northern Lapland. Int. J. Climatol. 2017, 37, 1257-1266. [CrossRef]

25. Kivilä, E.H.; Luoto, T.P.; Rantala, M.V.; Nevalainen, L. Long-term variability in chironomid functional assemblages and carbon utilization in a tundra lake food web. Hydrobiologia 2019, submitted.

26. Szeroczyńska, K.; Sarmaja-Korjonen, K. Atlas of Subfossil Cladocera from Central and Northern Europe; Friends of the Lower Vistula Society: Swiecie, Poland, 2007.

27. Kurek, J.; Korosi, J.B.; Jeziorski, A.; Smol, J.P. Establishing reliable minimum count sizes for cladoceran subfossils sampled from lake sediments. J. Paleolimnol. 2010, 44, 603-612. [CrossRef]

28. Sarmaja-Korjonen, K. Chydorid ephippia as indicators of past environmental changes-A new method. Hydrobiologia 2004, 526, 129-136. [CrossRef]

29. Rao, C.R. Diversity and dissimilarity coefficients: a unified approach. Theor. Popul. Biol. 1982, $21,24-43$. [CrossRef]

30. Nevalainen, L.; Rautio, M. Spectral absorbance of benthic cladoceran carapaces as a new method for inferring past UV exposure of aquatic biota. Quat. Sci. Rev. 2014, 84, 109-115. [CrossRef] 
31. Solanki, S.K.; Usoskin, I.G.; Kromer, B.; Schüssler, M.; Beer, J. An unusually active Sun during recent decades compared to the previous 11,000 years. Nature 2004, 431, 1084-1087. [CrossRef]

32. Matskovsky, V.V.; Helama, S. Testing long-term summer temperature reconstruction based on maximum density chronologies obtained by reanalysis of tree-ring data sets from northernmost Sweden and Finland. Clim. Past 2014, 10, 1473-1487. [CrossRef]

33. Šmilauer, P.; Leps, J. Multivariate Analysis of Ecological Data Using Canoco 5; Cambridge University Press: Cambridge, UK, 2014.

34. Hammer, Ø.; Harper, D.A.T.; Ryan, P.D. Past: Paleontological statistics software package for education and data analysis. Palaeontol. Electron. 2001, 4,9.

35. Finstad, A.G.; Andersen, T.; Larsen, S.; Tominaga, K.; Blumentrath, S.; De Wit, H.A.; Tømmervik, H.; Hessen, D.O. From greening to browning: Catchment vegetation development and reduced S-deposition promote organic carbon load on decadal time scales in Nordic lakes. Sci. Rep. 2016, 6, 31944. [CrossRef] [PubMed]

36. Wauthy, M.; Rautio, M.; Christoffersen, K.S.; Forsström, L.; Laurion, I.; Mariash, H.L.; Peura, S.; Vincent, W.F. Increasing dominance of terrigenous organic matter in circumpolar freshwaters due to permafrost thaw. Limnol. Oceanogr. Lett. 2018, 3, 186-198. [CrossRef]

37. Bogard, M.J.; Kuhn, C.D.; Johnston, S.E.; Striegl, R.G.; Holtgrieve, G.W.; Dornblaser, M.M.; Spencer, R.G.M.; Wickland, K.P.; Butman, D.E. Negligible cycling of terrestrial carbon in many lakes of the arid circumpolar landscape. Nat. Geosci. 2019, 12, 180. [CrossRef]

38. Schindler, D.E.; Scheuerell, M.D. Habitat coupling in lake ecosystems. Oikos 2002, 98, 177-189. [CrossRef]

39. Griffiths, K.; Michelutti, N.; Sugar, M.; Douglas, M.S.V.; Smol, J.P. Ice-cover is the principal driver of ecological change in High Arctic lakes and ponds. PLoS ONE 2017, 12, e0172989. [CrossRef] [PubMed]

40. Thienpont, J.R.; Korosi, J.B.; Cheng, E.S.; Deasley, K.; Pisaric, M.F.; Smol, J.P. Recent climate warming favours more specialized cladoceran taxa in western Canadian Arctic lakes. J. Biogeogr. 2015, 42, 1553-1565. [CrossRef]

41. Rantala, M.V.; Luoto, T.P.; Weckström, J.; Perga, M.-E.; Rautio, M.; Nevalainen, L. Climate controls on the Holocene development of a subarctic lake in northern Fennoscandia. Quat. Sci. Rev. 2015, 126, 175-185. [CrossRef]

42. Mariash, H.L.; Devlin, S.P.; Forsström, L.; Jones, R.I.; Rautio, M. Benthic mats offer a potential subsidy to pelagic consumers in tundra pond food webs. Limnol. Oceanogr. 2014, 59, 733-744. [CrossRef]

43. Kultti, S.; Nevalainen, L.; Luoto, T.P.; Sarmaja-Korjonen, K. Subfossil chydorid (Cladocera, Chydoridae) ephippia as paleoenvironmental proxies: Evidence from boreal and subarctic lakes in Finland. Hydrobiologia 2011, 676, 23-37. [CrossRef]

44. Luoto, T.P.; Nevalainen, L.; Sarmaja-Korjonen, K. Multi-proxy evidence for the 'Little Ice Age' from Lake Hampträsk Southern Finland. J. Paleolimnol. 2008, 40, 1097-1113. [CrossRef]

45. Nevalainen, L.; Helama, S.; Luoto, T.P. Hydroclimatic variations over the last millennium in eastern Finland disentangled by fossil Cladocera. Palaeogeogr. Palaeoclimatol. Palaeoecol. 2013, 378, 13-21. [CrossRef]

46. Hooper, D.U.; Solan, M.; Symstad, A.; Diaz, S.; Gessner, M.O.; Buchmann, N.; Degrange, P.; Grime, P.; Hulot, F.; Mermillod-Blondin, F.; et al. Species diversity, functional diversity, and ecosystem functioning. In Biodiversity and Ecosystem Functioning. Synthesis and Perspectives; Loreau, M., Naeem, S., Inchausti, P., Eds.; Oxford University Press: Oxford, UK, 2002; pp. 95-281.

47. Nevalainen, L.; Brown, M.; Manca, M. Sedimentary record of cladoceran functionality under eutrophication and reoligotrophication in Lake Maggiore, northern Italy. Water 2018, 10, 86. [CrossRef]

48. Clark, G.F.; Stark, J.S.; Johnston, E.L.; Runcie, J.W.; Goldsworthy, P.M.; Raymond, B.; Riddle, M.J. Light-driven tipping points in polar ecosystems. Glob. Chang. Biol. 2013, 19, 3749-3761. [CrossRef] [PubMed]

49. Laurion, I.; Ventura, M.; Catalan, J.; Psenner, R.; Sommaruga, R. Attenuation of ultraviolet radiation in mountain lakes: Factors controlling the among-and within-lake variability. Limnol. Oceanogr. 2000, 45, 1274-1288. [CrossRef]

50. Nevalainen, L.; Luoto, T.P.; Rantala, M.V.; Galkin, A.; Rautio, M. Role of terrestrial carbon in aquatic UV exposure and photoprotective pigmentation of meiofauna in subarctic lakes. Freshw. Biol. 2015, 60, 2435-2444. [CrossRef]

51. Nevalainen, L.; Rantala, M.V.; Luoto, T.P.; Rautio, M.; Ojala, A.E.K. Ultraviolet radiation exposure of a high arctic lake in Svalbard during the Holocene. Boreas 2015, 44, 401-412. [CrossRef] 
52. Nevalainen, L.; Rantala, M.V.; Luoto, T.P.; Ojala, A.E.K.; Rautio, M. Long-term changes in pigmentation of arctic Daphnia provide potential for reconstructing aquatic UV exposure. Quat. Sci. Rev. 2016, 144, 44-50. [CrossRef]

53. Nevalainen, L.; Rantala, M.V.; Rautio, M.; Luoto, T.P. Spatio-temporal cladoceran (Branchiopoda) responses to climate change and solar radiation in subarctic ecotonal lakes. J. Biogeogr. 2018, 45, 1954-1965. [CrossRef]

54. Helama, S.; Jones, P.D.; Briffa, K.R. Dark Ages Cold Period: A literature review and directions for future research. Holocene 2017, 27, 1600-1606. [CrossRef]

55. Linderholm, H.W.; Nicolle, M.; Francus, P.; Gajewski, K.; Helama, S.; Korhola, A.; Solomina, O.; Yu, Z.; Zhang, P.; D'Andrea, W.J.; et al. Arctic hydroclimate variability during the last 2000 years-current understanding and research challenges. Clim. Past 2018, 14, 473-514. [CrossRef]

56. Quesada, A.; Fernandez-Valiente, E.; Hawes, I.; Howard-Williams, C. Benthic primary production in polar lakes and rivers. In Polar Lakes and Rivers. Limnology of Arctic and Antarctic Aquatic Ecosystems; Vincent, V.F., Laybourn-Parry, J., Eds.; Oxford University Press: Oxford, UK, 2008; pp. 179-196.

57. Rodríguez, P.; Ask, J.; Hein, C.L.; Jansson, M.; Karlsson, J. Benthic organic carbon release stimulates bacterioplankton production in a clear-water subarctic lake. Freshw. Sci. 2013, 32, 176-182. [CrossRef]

58. Sierszen, M.E.; McDonald, M.E.; Jensen, D.A. Benthos as the basis for arctic lake food webs. Aquat. Ecol. 2003, 37, 437-445. [CrossRef]

59. Bonilla, S.; Villeneuve, V.; Vincent, W.F. Benthic and planktonic algal communities in a high arctic lake: Pigment structure and contrasting responses to nutrient enrichment. J. Phycol. 2005, 41, 1120-1130. [CrossRef]

60. Lionard, M.; Péquin, B.; Lovejoy, C.; Vincent, W.F. Benthic cyanobacterial mats in the high arctic: Multi-layer structure and fluorescence responses to osmotic stress. Front. Microbiol. 2012, 3, 140. [CrossRef] [PubMed]

61. Vinebrooke, R.D.; Leavitt, P.R. Differential responses of littoral communities to ultraviolet radiation in an alpine lake. Ecology 1999, 80, 223-237. [CrossRef]

(C) 2019 by the authors. Licensee MDPI, Basel, Switzerland. This article is an open access article distributed under the terms and conditions of the Creative Commons Attribution (CC BY) license (http://creativecommons.org/licenses/by/4.0/). 